\title{
Teacher education for an uncertain future: Implications of PISA's Global Competence
}

\author{
Donella J Cobb and Daniel Couch ${ }^{1}$
}

\begin{abstract}
In 2018, the Organisation for Economic Co-operation and Development's (OECD) is set to introduce an assessment of Global Competence in its Programme for International Student Achievement (PISA). This assessment lays the foundation for a set of knowledge, skills, values and beliefs that the OECD considers necessary to become a globally competent citizen. Throughout this chapter we identify and critique the intended socialising function of PISA's Global Competence, and consider its implications for Initial Teacher Education (ITE). We do this by drawing on Bernstein's theoretical tools to engage in a critical analysis of PISA's Global Competence framework. Our analysis reveals three key findings: 1) PISA's Global Competence acts as a symbolic regulator of consciousness; 2) PISA's Global Competence facilitates a new form of global pedagogic governance, and 3) ITE can play an important role in either reproducing, disrupting or transforming the socialising function of PISA's Global Competence. In conclusion we argue that engaging with Comparative and International Education scholarship will prepare pre-service teachers to respond to the complexities and demands of an uncertain educational future within an increasingly globalised educational landscape.
\end{abstract}

Keywords: PISA, Global Competence, Bernstein, Initial Teacher Education, Comparative and International Education,

\subsection{Introduction}

It might be said that the only certainty in the future of education is its uncertainty. There is, however, a case to be made for a further certainty; that with growing frequency and speed, local education ideas, policies, and practices will be increasingly determined by responses to global events, debates and agendas (Robertson, 2016). Education policy is increasingly being influenced or determined by events and policy groups which operate on an international level (Volante \& Fazio, 2018). This is not a new phenomenon. However, the intensity of this interconnectedness, and the growth of pathways for education ideas to travel between global and local, leads to a rising uncertainty for the future of education. This chapter raises critical

\footnotetext{
${ }^{1}$ D. J. Cobb, The University of Waikato, Hamilton, New Zealand email: donella.cobb@waikato.ac.nz

D. Couch, The University of Auckland, Auckland, New Zealand email: d.couch@auckland.ac.nz
}

Cobb, D., \& Couch, D. (2018). Teacher education for an uncertain future: Implications of PISA's global competence. In D. Heck, \& A. Ambrosetti (Eds.), Teacher Education in and for Uncertain Times (pp. 35-47). Springer. Retrieved from https://link.springer.com/chapter/10.1007/978-981-10-8648-9_3 
awareness to the socialising function of Programme for International Student Achievement's (PISA) Global Competence, and considers the implications for Initial Teacher Education (ITE).

In 2016, the Organisation for Economic Co-operation and Development (OECD) signaled its proposal to include Global Competence in its 2018 PISA measurement. Defined as the ability to "mobilise knowledge, skills, attitudes and values" (OECD, 2016, p. 2), this assessment of Global Competence intends to prepare students "to engage with and act in the world" (p. 2). The OECD defines Global Competence as the:

capacity to analyse global and intercultural issues critically and from multiple perspectives, to understand how differences affect perceptions, judgements, and ideas of self and others, and to engage in open, appropriate and effective interactions with others from different backgrounds on the basis of a shared respect for human dignity (OECD, 2016, p. 4).

15-year olds in approximately 80 countries will be tested on their knowledge, skills, values and attitudes towards global competence. This includes their knowledge of global issues, their ability to speak more than one language and the demonstration of their attitudes towards cultural diversity. Evidence from this assessment is intended to provide governments with data to reform education policy, curriculum development and teacher education programmes (OECD, 2016). Teacher education and professional training are considered central to the implementation of Global Competence, and the OECD argues that there is a critical need for Initial Teacher Education (ITE) to “address and support teachers' global competence development" (OECD, 2016, p. 19). However, this radical move to reform education based on an assessment of globally regulated values, attitudes, skills and knowledge brings considerable uncertainty, particularly for teacher education. What does this mean for the future of teacher education? How can educators, academics and ITE providers best prepare pre-service teachers for this increasingly uncertain future?

In this chapter we examine the OECD's Global competency for an inclusive world (OECD, 2016) framework. This framework outlines the introduction of Global Competence into PISA's upcoming 2018 assessment. The chapter begins with an overview of critical policy scholarship on the OECD and PISA, before positioning this study within critical realism. We then draw on Bernstein's theoretical tools to argue that PISA's Global Competence operates as a symbolic regulator of consciousness to shape a new form of pedagogic identity that serves the interests of a global marketplace. We demonstrate how ITE plays an important role in this identity reconstruction by either reproducing or disrupting these new pedagogic identities. We conclude by stating that stronger engagement with the field of Comparative and International Education (CIE) will prepare pre-service teachers for uncertain futures within an increasingly globalised educational landscape.

Cobb, D., \& Couch, D. (2018). Teacher education for an uncertain future: Implications of PISA's global competence. In D. Heck, \& A. Ambrosetti (Eds.), Teacher Education in and for Uncertain Times (pp. 35-47). Springer. Retrieved from https://link.springer.com/chapter/10.1007/978-981-10-8648-9_3 


\subsection{The OECD's education agenda}

The origins of the OECD and PISA are well chronicled. It is not our intent to replicate that historiography here, however it is important to understand the organisational intent of the OECD in order to examine the ideation of PISA's Global Competence. To this end, we briefly explore literature from critical policy scholarship on the OECD and PISA. The OECD's convention of 1961 sets out its purpose as "promoting sustainable economic growth and development, maximising employment and living standards, and nurturing the global trading regime” (Woodward, 2009, p. 4). Membership states come from 35 of the most advanced national economies in the world, although, in recent times, this has extended to emerging economies such as Mexico, Chile, and Turkey. The organisation is multifaceted, operating simultaneously as a "geographic entity, an organisational structure, a policy-making forum, a network of policy makers, researchers and consultants, and a sphere of influence” (Henry et al., 2001, p. 7). The OECD operates solely within the realm of ideas, which leads it to occupy a particular realm of influence in setting the current global education agenda (Sellar \& Lingard, 2014). Whilst education had always had an inferred role within the organisation, this became explicit during the 1990s (Lingard \& Sellar, 2016).

Since its inception, the OECD's interest in education has always been framed by economic concerns (Lingard \& Sellar, 2016). A key justification for the explicit policy focus on education during the late 1990s was driven by a wide subscription to human capital theory and the global emergence of a knowledge economy. Within human capital theory, education plays an instrumental economic role as it develops the individuals who constitute "a highly skilled and flexible workforce [essential] to national success within the new global knowledge economy” (Henry et al., 2001, p. 30). This saw a shift away from perceiving education's primary benefit as collective (public good), and towards the individual (private good). The knowledge economy regarded education "as the policy key to the future prosperity of nations" (Henry et al., 2001, p. 30), and this drove OECD member states to call for education data that could be internationally comparative "as surrogate measures of the potential global competitiveness of national economies" (Sellar \& Lingard, 2014, p. 918). The OECD duly began to develop tools to gather and compare educational attainment (Lingard \& Sellar, 2016; Volante \& Fazio, 2018). The Programme for International Student Assessment was the result.

PISA international assessments take place every three years to assess the skills and knowledge of 15-year olds in member and non-member countries who volunteer to take part. Using a subject-based cycle, PISA measures literacy, mathematics and science once every three years with the aim of creating an "internationally comparative evidence base for educational policy development and implementation” (Wiseman, 2013, p. 304). 43 countries were involved in the first PISA assessment; however, by 2015 over half a million students who were representative of 29 million 15-year-olds, were assessed in 72 countries (OECD, 2017). Generating such a significant amount of data, PISA “is one of the largest non-experimental

Cobb, D., \& Couch, D. (2018). Teacher education for an uncertain future: Implications of PISA's global competence. In D. Heck, \& A. Ambrosetti (Eds.), Teacher Education in and for Uncertain Times (pp. 35-47). Springer. Retrieved from https://link.springer.com/chapter/10.1007/978-981-10-8648-9_3 
research exercises the world has ever seen” (Murphy, 2014, p. 898). With big data comes big influence. PISA has enabled the OECD to position itself as a primary influencer within the global education agenda. Many authors point to PISA as a key mechanism of global educational governance, in which OECD member countries leverage their position within the organisation to effectively direct national-level education reforms in member and nonmember states alike (Lingard \& Lewis, 2017; Volante \& Fazio, 2018). Nations have used PISA's international comparisons to identify their educational problems and have responded by reforming their education systems and policies in an attempt to 'move up' the rankings (Meyer \& Benavot, 2013; Wiseman, 2013). This has further legitimised the role of international organisations to examine and dissect successful school systems with the aim of implementing internationally standardised curricula, pedagogy and ITE programmes as a panacea for failing education systems (Münch 2014).

It is clear from this review of literature that PISA influences national forms of education delivery. This positions teacher education within a rapidly changing and uncertain landscape, which encourages national education institutions to increasingly align and conform with PISA structures (Münch, 2014). Ultimately, this has the potential to rob local institutions, such as ITE providers, of their legitimacy and keep them "in a state of uncertainty for decades" (Münch, 2014, p. 13). This state of uncertainty for teacher education is even more imminent with the OECD's recent proposal to include the assessment of Global Competence in the 2018 PISA (OECD, 2016). Below, we analyse the Global competency for an inclusive world (OECD, 2016) in order to identify the potential implications of PISA's Global Competence on national ITE programmes.

\subsection{A Bernstenian analysis of PISA's Global Competence}

In recent years, there has been a growing interest in "putting Bernstein's theories to work" (Robertson \& Sorensen, 2017, p. 3) to theorise global processes and global governance (Singh, 2015; 2017; Tyler, 2010). The explanatory power of both Bernstein's theoretical tools and his notion of a Totally Pedagogised Society (TPS) have been particularly useful for examining global policies and global governance. In his later work Bernstein hypothesised that a market-oriented ideology would shape new forms of pedagogic identity to serve the interests of the market place (Bernstein, 2001). He used the term TPS to vaticinate an emerging society that he believed would shape and sustain social order by embedding discursive principles of pedagogy throughout the fabric of social life. It is through the internal shaping of consciousness, aspirations, desires and conduct that governments would gain symbolic control of the pedagogic space. Bernstein predicted that this space would socialise actors to serve the rapidly changing labour needs of a global marketplace. Of late, a growing number of scholars have extrapolated Bernstein's thesis beyond the boundaries of the nationstate to examine how supranational organisations, such as the OECD, have used pedagogic tools to gain symbolic control over regional and global pedagogic spaces (see Robertson \&

Cobb, D., \& Couch, D. (2018). Teacher education for an uncertain future: Implications of PISA's global competence. In D. Heck, \& A. Ambrosetti (Eds.), Teacher Education in and for Uncertain Times (pp. 35-47). Springer. Retrieved from https://link.springer.com/chapter/10.1007/978-981-10-8648-9_3 
Sorensen, 2017; Tyler, 2010). In doing so, these scholars add weight to Bernstein's vaticination that a TPS would see symbolic power transform education from being a reproducer of society, to becoming a shaper of consciousness.

What makes Bernstein's work particularly relevant to our examination of PISA's Global Competence is the way he also developed a conceptual grammar to address the relationship between actors and agencies in both the transmission and acquisition of knowledge, and the production and regulation of consciousness and disposition (Bernstein, 2001). He sought to understand the social significance of these pedagogical relationships and the way that they shape cultural production, reproduction and disruption. This engagement with multiple actors and agencies is particularly useful when examining the pedagogical significance of a tool such as PISA's Global Competence. Actors and agencies can operate as agents of this symbolic control by performing various roles and functions. Bernstein (2001) defines symbolic control as "the means where consciousness, dispositions and desire are shaped and distributed through forms of communication which relay and legitimate a distribution of power and cultural categories" (p. 23). He views this field of symbolic control as a division of labour, which he suggests is divided into "specialised discourses, agents and agencies" (p. 23). For example, Bernstein maintains that teachers and schools fulfill a reproductive function while academics and institutions, such as ITE providers, can play either a reproductive role by reproducing the ideas and practices produced by governments, or a transformative role by disrupting oppressive ideologies and shaping new ideas and knowledge. We return to this point later in this chapter in our analysis of PISA's Global Competence.

Bernstein (2000) maintains that biases are embedded within educational transmission. He sets out the notion of a 'pedagogic device' to describe the mechanisms which relay biases and ideological messages. Pedagogic devices provide a valuable way to understand how the process of producing, transmitting and acquiring knowledge shapes and reshapes pedagogic identities. The pedagogic device therefore has a dual role: to act as a symbolic regulator of consciousness while also facilitating the production, reproduction and transformation of culture. Ideologies are constructed as a result of changing values in education systems. Bernstein prompts us to question the agenda behind educational changes by asking "which group is responsible for initiating the change?" (2000, p. 15), and whether such change is initiated by a dominant or a dominated group. These questions encourage us to consider why the OECD is interested in assessing certain knowledge, values and beliefs, and whose interests this information serves. An analysis of these biases is necessary to understand the social significance of this educational transmission. Bernstein (2000) identifies three rules to analyse these biases and ideological messages within this pedagogic device: the distributive rule, the recontextualising rule and the evaluative rule.

Cobb, D., \& Couch, D. (2018). Teacher education for an uncertain future: Implications of PISA's global competence. In D. Heck, \& A. Ambrosetti (Eds.), Teacher Education in and for Uncertain Times (pp. 35-47). Springer. Retrieved from https://link.springer.com/chapter/10.1007/978-981-10-8648-9_3 
The distributive rule refers to the way in which a phenomenon becomes legitimised. This occurs in the abstract; something that was not previously thought is thought, and thus becomes possible to know. Bernstein (2000) argues that this distributive rule creates, produces and distributes pedagogic discourse to privilege the dominant social group. In the case of the OECD's framework, the idea that all people can possess universal skills, values, attitudes and knowledge independent from local cultural practices is legitimated through the establishment of PISA's Global Competence assessment. This universal individual is set out and justified by OECD's Chief of Staff Ramos in her introductory comments to the framework:
Against a context in which we all have much to gain from growing openness and connectivity, and much to lose from rising inequalities and radicalism, citizens need not only the skills to be competitive and ready for a new world of work, but more importantly they also need to develop the capacity to analyse and understand global and intercultural issues. (OECD, 2016, p. ii)

Ramos presents global competency as the answer to rising inequalities and radicalism, stating that "global competencies is vital for individuals to thrive in a rapidly changing world and for societies to progress without leaving anyone behind" (OECD, 2016, p. ii). At this first level of analysis we begin to see how PISA's global competence assessment lays a foundation for legitimising universal attributes and enables the OECD to gain symbolic control of the global pedagogic space.

Bernstein's notion of recontextualisation considers how ideas, such as global competence, take on new meaning as they are transmitted between actors and contexts. During this transmission, a new form of the original idea takes shape. This could be understood in terms of a Trojan Horse, whereby a seemingly innocuous or even positive notion obfuscates an alternative intent. Herein lies the crux of our argument, as we make the case that recontextualisation occurs within the ideation of Global Competence. The framework clearly identifies certain values, attitudes and skills that the OECD believes should be possessed by all. In this initial construction of the idea, several positive and desirable attributes are presented. These include attitudes of openness towards people, respect for cultural otherness, global mindedness and responsibility. It also includes the ability to interact respectfully, with empathy and flexibility (OECD, 2016, p. 13). In addition, it maintains that individuals should have the ability to speak another language. However, a thematic analysis of the framework illustrates the underpinning dominance of human capital theory. It makes the case that "both employers and policy-makers... need an evidence-based approach to teaching and assessing global competence” (p. 3). Certain skills, values and behaviours are privileged to meet employers' needs within a global marketplace. In this way, the original concept of Global Competence is recontextualised from meeting largely social goals in order to advance a neoliberal agenda across national education curricula and ITE programmes.

Cobb, D., \& Couch, D. (2018). Teacher education for an uncertain future: Implications of PISA's global competence. In D. Heck, \& A. Ambrosetti (Eds.), Teacher Education in and for Uncertain Times (pp. 35-47). Springer. Retrieved from https://link.springer.com/chapter/10.1007/978-981-10-8648-9_3 
Finally, the evaluative rule ensures that knowledge, skills, values and attitudes are both taught and acquired. Bernstein (2000) explains that the evaluative rule is responsible for regulating the 'what' and 'how' of teaching by setting standards, legitimating content, determining the form of transmission and regulating the way that knowledge is distributed to different groups in different contexts. Within the Global Competence framework, a particular emphasis is placed on pedagogic interaction. This suggests that teachers will need to "act as facilitators in activities" (OECD, 2016, p. 18) to aid the development of Global Competence, and that learner-centred pedagogy is an "innovative teaching and learning method" (p. 18) that should be supported by "the official curriculum and education authorities" (p. 19). This explicit focus on pedagogy is intended to ensure that students gain the acquisition of the skills, attitudes, values and knowledge set out by the OECD in their ideation of the globally competent individual. In light of the identified foundation of human capital theory, the evaluative rule in this context facilitates the socialisation of students to think, behave and act in certain ways that serve the interests of a globalised labour market.

\subsection{The 'PISA effect' and teacher education}

This analysis of PISA's Global Competence framework reveals three key findings. Firstly, by understanding PISA's Global Competence as a pedagogic device, its capacity to act as a symbolic regulator of consciousness is uncovered. Our analysis of the Global Competence framework has identified an underlying intent within the notion of Global Competence which orients education further towards market interests. Labaree (2014) claims that a certain type of worker is needed to grow market economies. This has seen the OECD engineer the development of cognitive skills that are considered necessary for workers in a global marketplace (Labaree, 2014). PISA performs a crucial function in the development of this human capital production by not only establishing the criteria for the globalisation of certain skills, but by providing a "measure of human capital flows into economies" (Sellar \& Lingard, 2013, p. 193). This has shifted the focus of assessment from understanding what people know or what people can do, to quantifying "who people are and who they could become” (Sellar \& Lingard, 2013, p. 196). Münch (2014) suggests that this refocused emphasis on human capital production keeps local institutions such as schools and ITE providers in an ongoing state of uncertainty. This presents an opportunity to subtly erode and deconstruct their foundations to conform with PISA's subscription to human capital theory. By understanding PISA's Global Competence as a pedagogic device, we can see how the framework intends to reshape pedagogic identities by socialising the skills, values, behaviours and dispositions that advance human capital production.

Our second finding builds on this conceptualisation of PISA's Global Competence as a pedagogic device and proposes that PISA's Global Competence contributes to a new form of global pedagogic governance. The OECD signals that data gathered from the PISA Global Competence assessment is intended to drive national curricula reform (OECD, 2016, p. 12).

Cobb, D., \& Couch, D. (2018). Teacher education for an uncertain future: Implications of PISA's global competence. In D. Heck, \& A. Ambrosetti (Eds.), Teacher Education in and for Uncertain Times (pp. 35-47). Springer. Retrieved from https://link.springer.com/chapter/10.1007/978-981-10-8648-9_3 
This increasing control over the 'what' and 'how' of learning and teaching at all levels of education suggests that the OECD is positioned to gain increasing governance of the global pedagogic space. Bernstein (2001) raised concern that governance would be increasingly obtained by pedagogic means in order to serve market interests. Our analysis of PISA's Global Competence framework points to such concerns. Pykett (2009) refers to the way in which pedagogic governance is outworked through developing competences "in every area of life" (p. 108) rather than regulating actors by external rules or direct instruction. As previously demonstrated, PISA's Global Competence appears to fulfill this function by reshaping consciousness, dispositions and desires to address the needs of the market. Thus, this reorienting of pedagogic identity now seems to align with the OECD's core function; that is, to grow market economies (Tröhler et al., 2014). This positions the OECD to better gain symbolic control of the global pedagogic space, increasing the OECD's power to govern global education reform through indirect means.

This increasing alignment between pedagogic governance and social control is what Bernstein (2001) referred to as a Totally Pedagogised Society (TPS). Singh (2015) reminds us that a TPS creates new regimes of power by establishing new ways to communicate social control (Singh, 2015). PISA's Global Competence appears to provide an important symbolic tool to establish these new routines of introspection and regimes of power and social control. Bernstein predicted that a move towards a TPS would reposition education away from being a reproducer of society and towards playing a leading role in establishing and legitimating society. Our first finding illustrates how the framework is significant in reorienting education to become a shaper of consciousness, uncovering a new mode of regulation, governance and social control in the process (Singh, 2017). However, Bernstein's concern with such reorientation moves beyond simply determining modes of power and control. Rather, he argues that such understanding must lead to consideration of how social inequalities are reproduced, resisted, disrupted and transformed "through these new modes and networks of pedagogic communication” (Singh, 2015, p. 365). To respond to these concerns, our final finding briefly examines the agents and agencies of symbolic control.

Our third key finding demonstrates how ITE plays an important role in either reproducing, or disrupting and transforming, pedagogic identities. Bernstein (2001) prompts us to look beyond the surface features of this pedagogic governance to consider the groups who are expected to acquire these pedagogic identities and the conditions in which these identities are to be acquired. We return to the notion of agents and agencies of symbolic control that were introduced earlier in this chapter to consider how PISA's "regime of global governance" (Myer \& Benavot, 2013, p. 7) influences local ITE programmes. From the OECD's perspective, ITE plays an important role in enacting PISA's policies (Lingard \& Lewis, 2017) and shaping and reproducing these new pedagogic identities. For example, the OECD argues that there is a critical need for ITE to “address and support teachers' global competence

Cobb, D., \& Couch, D. (2018). Teacher education for an uncertain future: Implications of PISA's global competence. In D. Heck, \& A. Ambrosetti (Eds.), Teacher Education in and for Uncertain Times (pp. 35-47). Springer. Retrieved from https://link.springer.com/chapter/10.1007/978-981-10-8648-9_3 
development" (OECD, 2016, p. 19). It states that "teacher education and professional training are crucial to the successful implementation of global competence education” (p. 19) and, because of this, an entire section of the Global competency for an inclusive world framework (OECD, 2016) is dedicated to the development of Global Competence in teachers and teacher preparation programmes. It signals that the 2018 PISA will evaluate how well teacher education programmes prepare teachers to become "globally competent" (OECD, 2016, p. 3). As Bernstein (2000) points out, new pedagogical practices and curriculum content are easily acquired when there is a systematic means through which to regulate acquisition. The OECD's intent to evaluate teacher education programmes signals a strong desire to ensure that ITE providers produce globally competent teachers who, in turn, can reproduce the OECD's interpretation of a globally competent student.

However, institutions such as ITE providers can also play an important role as shapers of ideas and knowledge and can be "a force for change and development" (Bernstein, 2001, p. 27). For this reason, agents operating within these institutions, such as teacher educators and academics, have the potential to disrupt the market-oriented socialisation of new pedagogic identities and restore notions of global competences to their original intent. In other words, agencies such as ITE and actors such as pre-service teachers can be agents of change and transformation. It is here where Bernstein's conceptual tools allows us to understand the power of human agency to transform reproductive power structures, a notion that is central to critical realist ontology. But in what ways can teacher educators and ITE providers resist, disrupt and transform this market-driven orientation of global competences? How can ITE providers best prepare pre-service teachers to gain critical awareness of their work within an increasingly globalised society? To respond to these questions we turn to the field of Comparative and International Education (CIE) to demonstrate how such scholarship can bring critical awareness to global processes, policies and reforms.

\subsection{Making a case for Comparative and International Education}

Teacher education plays an important role in preparing pre-service teachers to have critical awareness of education reform. Zhao (2010) maintains that teachers "need to have a broad understanding of globalisation" so that they can "interpret the realities of globalisation on behalf of their students” (p. 426). He suggests that teachers should have critical awareness of the impact of international and government policies as well as the ability and courage to speak up to defend the future of their students. Teacher education can raise pre-service teachers' critical awareness by helping them understand "how broader social forces influence schooling and the curriculum" (Wang et al., 2011, p. 116). This understanding can provide pre-service teachers with the capacity to identify, and the ability to resist and transform, changes to education policy, structures and curricula (Wang et al., 2011; Zhao, 2010).

Cobb, D., \& Couch, D. (2018). Teacher education for an uncertain future: Implications of PISA's global competence. In D. Heck, \& A. Ambrosetti (Eds.), Teacher Education in and for Uncertain Times (pp. 35-47). Springer. Retrieved from https://link.springer.com/chapter/10.1007/978-981-10-8648-9_3 
The field of CIE provides a valuable foundation to prepare pre-service teachers to engage with these concerns. As CIE is "dedicated to increasing the understanding of educational issues, trends and policies, through comparative, cross cultural and international perspectives” (Comparative and International Education, 2017, n.p.), it is well equipped to prepare pre-service teachers with this global awareness and critical insight in two important ways. Firstly, CIE can prepare pre-service teachers to gain greater critical awareness of their work within an increasingly globalised society (Robertson \& Dale, 2015). When examining CIE programmes at the University of Auckland and Sydney University, Shah, McCormick and Thomas (2017) found that both programmes promoted an understanding of "the dialectic that exists between the local and global, but with clear attention to the tensions and clashes which neoliberal globalisation brings about...[and] critical deconstructions of binaries and taken for granted justificatory narratives” (p. 58). The intent to develop such a critical awareness of global and local influences on education is an important first step in resisting the production and reproduction of market-oriented pedagogic identities. In this regard, CIE can prepare pre-service teachers with the knowledge, skills, attitudes and behaviours to expose, critique and resist harmful educational reforms (Robertson, 2008, 2016).

Secondly, CIE can provide pre-service teachers with an authentic understanding of cross-cultural awareness. Much CIE scholarship places value on the cultural knowledge, values, practices and beliefs and this has the potential for pre-service teachers to develop an authentic, rather than a market-driven interpretation of cross-cultural awareness. For example, O'Sullivan et al., (2010) found that pre-service teachers undertaking CIE classes in Ireland and South Africa developed a much broader and critical understanding of education, which strengthened teachers' own abilities to teach in multi-cultural classrooms. This example is one of many which shows that CIE is an important field of scholarship for raising authentic, cross-cultural awareness of the dynamic relationships between global and local sites of education. It therefore has a powerful role to play in supporting agents such as academics, teacher educators and pre-service teachers with the knowledge to resist, disrupt and transform market-orientated interpretations of what it means to be a globally competent citizen.

\subsection{Conclusion}

Bernstein (2000) prompts us to make notions of power and control visible in any new educational reform so we can challenge and transform hidden assumptions that lead to unequal outcomes. In this chapter we have identified and critiqued the socialising function of PISA's Global Competence and considered this in light of the intended widespread reforms for ITE. Through a Bernstenian analysis of the conceptual grammar within the OECD's Global competency for an inclusive world (OECD, 2016) framework, we have uncovered three key findings. Firstly, we conceptualised PISA's Global Competence as a pedagogic device to demonstrate how it has the capacity to act as a symbolic regulator of consciousness. We showed how this has the potential to rescript pedagogic identities to facilitate the production of human capital for the global labour market. Secondly, we demonstrated how

Cobb, D., \& Couch, D. (2018). Teacher education for an uncertain future: Implications of PISA's global competence. In D. Heck, \& A. Ambrosetti (Eds.), Teacher Education in and for Uncertain Times (pp. 35-47). Springer. Retrieved from https://link.springer.com/chapter/10.1007/978-981-10-8648-9_3 
PISA's Global Competence is one of several symbolic tools produced by the OECD to construct a new form of global pedagogic governance. We theorised that this shift reflects a move towards what Bernstein referred to as a TPS by aligning pedagogic governance with social control. Finally, we considered how ITE could play an important role in either reproducing, or disrupting and transforming, the socialising function of PISA's Global Competence. We suggest that the field of CIE is integral to support ITE programmes to: 1) prepare pre-service teachers to gain greater critical awareness of their work within an increasingly globalised society; and, 2) prepare pre-service teachers with the knowledge, skills, attitudes and behaviours to expose, critique and resist harmful education reforms. In this way, we argue that engagement with CIE will better prepare pre-service teachers for uncertain futures within an increasingly globalised educational landscape. 


\section{References}

Bernstein, B. (2000). Pedagogy, Symbolic Control and Identity: Theory, research, critique (Revised Ed). Lanham: Rowman \& Littlefield Publishers Inc.

Bernstein, B. (2001). Symbolic control: Issues of empirical description of agencies and agents. International Journal of Social Research Methodology, 4(1), 21-33

Comparative and International Education. (2017). Comparative and International Education Society. http://www.cies.us

Henry, M., Lingard, B., Rizvi, F., \& Taylor, S. (2001). The OECD, Globalisation and Education Policy. Oxford: IAU Press.

Labaree, D. F. (2014) Let's measure what no one teaches: PISA, NCLB, and the shrinking aims of education. Teachers College Record 116, 1-14.

Lingard, B., \& Lewis, S. (2017). Placing PISA and PISA for schools in two federalisms, Australia and the USA. Critical Studies in Education, 58(3), 1-14. https://doi.org/10.1080/17508487.2017.1316295

Lingard, B., \& Sellar, S. (2016). The Changing Organizational and Global Significance of the OECD's Education Work. The Handbook of Global Education Policy, 357-373. https://doi.org/10.1002/9781118468005.ch19

Meyer, H.-D., \& Benavot, A. (2013). PISA and the globalization of education governance: Some puzzles and problems. In H.-D. Meyer \& A. Benavot (Eds.), PISA, power, and policy: The emergence of global educational governance (pp. 7-26). Oxford: Symposium Books Ltd.

Münch. R. (2014). Education under the Regime of PISA \& Co.: Global Standards and Local Traditions in Conflict-The Case of Germany. Teachers College Record, 116, 1-1.

Murphy, D. (2014). Issues with PISA's use of its data in the context of international education policy convergence. Policy Futures in Education, 12(7), 893-916. https://doi.org/10.2304/pfie.2014.12.7.893

OECD. (2016). Global competency for an inclusive world. Paris: OECD.

OECD. (2017). PISA 2015 Assessment and Analytical Framework (PISA). Paris: OECD: OECD Publishing. https://doi.org/10.1787/9789264281820-en 
O’Sullivan, M, Maarman, R. F, Wolhuter, C. C. (2010) Primary student teachers' perceptions of and motivations for comparative education: Findings Findings from a comparative study of an Irish and South African comparative education course. Compare 38, 401414.

Pykett, J. (2009). Pedagogical power: Lessons from school spaces. Education, Citizenship and Social Justice, 4(2), 102-116

Robertson, S. L. (2008). "Remaking the World" Neoliberalism and the Transformation of Education and Teachers' Labor. In L. Weiner \& M. Compton (Eds.), The Global Assault on Teaching, Teachers, and their Unions Stories for Resistance (pp. 11-27). Basingstoke: Palgrave Macmillan. https://doi.org/10.1057/9780230611702

Robertson, S. L. (2016). The Global Governance of Teachers’ Work. In K. Mundy, A. Green, B. Lingard, \& A. Verger (Eds.), The Handbook of Global Education Policy (pp. 275290). West Sussex: John Wiley \& Sons. https://doi.org/10.1002/9781118468005.ch15

Robertson, S. L., \& Dale, R. (2015). Towards a “critical cultural political economy” account of the globalising of education. Globalisation, Societies and Education, 13(1), 149-170. https://doi.org/10.1080/14767724.2014.967502

Robertson, S. L., \& Sorensen, T. (2017). Global transformations of the state, governance and teachers' labour: Putting Bernstein's conceptual grammar to work. European Educational Research Journal, 0(0), 1-19. https://doi.org/10.1177/1474904117724573

Sellar, S., \& Lingard, B. (2013). PISA and the Expanding role of the OECD in Global Educational Governance. In: H-D Meyer. (Ed.), PISA, Power, and Policy: The Emergence of Global Governance (pp. 185 - 206). Oxford, United Kingdom: Symposium Books

Sellar, S., \& Lingard, B. (2014). The OECD and the expansion of PISA: New global modes of governance in education. British Educational Research Journal, 40(6), 917-936. https://doi.org/10.1002/berj.3120

Shah, R., McCormick, A., \& Thomas, M. A. M. (2017). Shifting tides: Reflecting on regional aspects of our roles as comparative and international educators. The International Education Journal: Comparative Perspectives, 16(3), 49-68.

Singh, P. (2015). Performativity and pedagogising knowledge: Globalising education policy formation, dissemination and enactment. Journal of Education Policy, 30(3), 363-384

Singh, P. (2017). Pedagogic governance: Theorising with/after Bernstein. British Journal of Sociology of Education, 38(2), 144-163

Tröhler, D., Meyer, H-D., Labaree, D. F., \& Hutt, E. (2014) Accountability: Antecedents, power, and processes. Teachers College Record 116, 1-12. competence. In D. Heck, \& A. Ambrosetti (Eds.), Teacher Education in and for Uncertain Times (pp. 35-47). Springer. Retrieved from https://link.springer.com/chapter/10.1007/978-981-10-8648-9_3 
Tyler, W. (2010). Towering TIMSS or Leaning PISA? Vertical and Horizontal models of international testing regimes. In P. Singh, A.R. Sadovnik and S.F. Semel (Eds.). Toolkits, translation devices and conceptual accounts: Essays on Basil Bernstein's sociology of knowledge (pp 143 - 159). New York: Peter Lang

Volante, L., \& Fazio, X. (2018). PISA, policy, and global educational governance. In L. Volante (Ed.), The PISA effect on global educational governance (pp. 3-14). New York: Routledge.

Wang, J., Lin, E., Spalding, E., Odell, S. J., \& Klecka, C. (2011). Understanding teacher education in an era of globalization. Journal of Teacher Education 62, 115-120.

Woodward, R. (2009). The Organisation for Economic Co-operation and Development. New York: Routledge.

Wiseman, A. W. (2013) Policy responses to PISA in comparative perspective. In H-D Meyer and A. Benavot (Eds.). PISA, power, and policy: The emergence of global educational governance. (pp.303 - 322). Oxford, U.K: Symposium Books

Zhao, Y. (2010). Preparing globally competent teachers: A new imperative for teacher education. Journal of Teacher Education 61, 422-431. 